менту дозволили порівняти не тільки гемостатичний і холестатичний ефекти різних видів енергії, але й оцінити ступінь травматизації паренхіми печінки в зоні оперативного втручання та вплив різних методів на якість і терміни процесів репарації. Експериментально доведено ефективність УЗС в досягненні остаточного гемостазу у разі кровотечі з ЛЖМ при холецистектомії. Встановлено, що глибина і ступінь дистрофічного процесу менше виражені при ультразвуковому впливі. Застосування УЗС при обробці ЛЖМ є безпечним і надійним методом зупинки паренхіматозної кровотечі та жовчовитікання з паренхіми печінки.

Ключові слова: кріовплив; печінка; ультразвуковий скальпель: електрокоагуляція.

\title{
COMPARATIVE CHARACTERISTICS OF THE APPLYING OF PHYSICAL METHODS AT CHOLECYSTECTOMY IN AN EXPERIMENT
}

\section{N. V. Cherkova, L. M. Dushik, G. M. Gerasymov, A. O. Dushik (Kharkiv, Ukraine)}

V. N. KarazinKharkiv National University, Department of surgical diseases

In an experiment on laboratory animals ( 84 male rabbits of Shinchilla breed weighing 3 to $3.5 \mathrm{~kg}$ ), the processes of liver tissue regeneration after cholecystectomy using electrocoagulation, cryoexposure and Harmonic scalpel (HS) at different terms were studied in a comparative aspect. The objective of the work: to study in the experiment histomorphological changes in the gallbladder bed under the influence of monopolar electrocoagulation, low temperatures and ultrasonic scalpel in a comparative aspect at cholecystectomy. Depending on the method of resection of the gallbladder and the method of hemostasis, all animals were divided into three groups. In Group I, after resection of the gallbladder, the animals underwent hemostasis of the gallbladder bed (GBB) with the help of monopolar electrocoagulation. In Group II, hemostasis was performed by the cryogenic treatment of GBB with a laparoscopic cryoapplicator. In group III, after cholecystectomy, the animals underwent hemostasis with HS. The results of the experiment made it possible to compare not only the hemostatic and cholestatic effects of various types of energy, but also to assess the grade of traumatization of the liver parenchyma in the operative intervention zone and the influence of various methods on the quality and terms of the reparative processes. The effectiveness of the HS in achieving final hemostasis with bleeding from GBB in cholecystectomy has been experimentally proven. It is determined that the depth and grade of the dystrophic process is less expressed with ultrasound exposure. The use of HS in the treatment of GBB was a safe and reliable method of stopping parenchymal hemorrhage and bile leakage from the liver parenchyma.

Key words: cryotherapy; liver; harmonic scalpel; electrocoagulation.

ОРГАНІЗАЦІЯ ОХОРОНИ ЗДОРОВ'Я

\section{ПРОБЛЕМИ ПОБУДОВИ МІЖНАРОДНОЇ КАРПАТСЬКОЇ ВАЛЕОЛОГІЧНОЇ ІННОВАЦІЙНОЇ СИСТЕМИ}

\author{
Національний університет «Львівська політехніка»<Mykola.V.Odrekhivskyi@lpnu.ua>, \\ $<$ orysia.o.pshyk-kovalska@1pnu.ua>
}

Досліджено особливості побудови Міжнародної карпатської валеологічної інноваційної системи на різних рівнях ї̈ організації. В рамках даного дослідження було обтрунтовано доцільність створення територіальних виробничих об'єднань. Висвітлено сутність категорії валеологічна інноваційна система як сукупність взаємозв'язаних організачій (підприємств), зайнятих виробництвом і комерціалізацією валеологічних інновачійних продуктів та продукиї у межах кордонів рекреаційних зон, які можуть 
охоплювати території декількох чи однієї країни. Виокремлено інфраструктурні компоненти валеологічної інноваційної системи, до яких віднесено рекропарки, рекрополіси та курортополіси, рекреаційні бізнес-інкубатори та валеологічні інноваційні центри, а також інститути правового, фінансового і соціального характеру, щуо забезпечують й обслуговують валеологічні інноваційні процеси. Розроблено організачійну модель валеологічного інноваційного підприємства. В рамках підвищення ефективності роботи валеологічного інноваційного підприємства було проаналізовано системи управління ним на засадах використання системного, синергетичного, гомеостатичного та синтелектуального підходів. Було встановлено, щчо об'єкту управління (валеологічному інноваційному процесу) й органам управління, щзо входять до структури валеологічного інноваційного підприємства, властивий необмежений характер розвитку. Обтрунтовано доиільність моделювання Міжнародної карпатської валеологічної інноваційної системи мережною моделлю. Дану модель було сформовано у вигляді кластерної, територіально-ієрархічної моделі як однієї з різновидностей мережних моделей, складовими якої можуть бути Карпатські валеологічні інноваиійні системи країн Карпатського єврорегіону.

Ключові слова: валеологічна інноваційна система; валеологічний інноваційний продукт; валеологічне інноваційне підприємство.

Вступ. Актуальність даного дослідження зумовлена необхідністю та доцільністю побудови Міжнародної карпатської валеологічної інноваційної системи (МКВIC) через високу смертність населення у країнах Карпатського єврорегіону (Україна - 16,2 \%о, Угорщина - 13,2 \%о, Румунія - 12,1 \%о, Польща - 10,5 \%о, Словаччина - 9,5 \%о станом на 1 січня 2013 р.) [6, с. 82-83], що в 2 рази перевищує смертність людського виду, яка становить 4-5 \%, і це при достатньо високому рекреаційному потенціалі Карпат та відповідно неефективному його використанні. Тому валеологічний інноваційний процес у Карпатській рекреаційній зоні повинен включати учасників з України, Польщі, Словаччини, Угорщини та Румунії, тобто з усіх країн Карпатського єврорегіону. Оскільки інноваційна активність великих, середніх і малих валеологічних організацій різниться, що зумовлено різною стратегією їх діяльності, то це зумовлює множинність організаційних форм інноваційної діяльності: від валеологічних бізнес-інкубаторів, які допомагають реалізувати валеологічні проекти на початковій стадії існування фірми, до стратегічних альянсів, покликаних реалізувати складні інноваційні проекти, в тому числі міжнародного рівня. Розвиток валеологічних інноваційних систем (BIC) загалом вимагає формування горизонтальної та вертикальної організації валеологічних інноваційних циклів, з виходом їх на міжнародні структури, тому дослідження проблем побудови МКВІС актуальне і необхідне.

Мета дослідження - розробити методологічні підходи до побудови Міжнародної карпатської валеологічної інноваційної системи на різних рівнях іiі організації.

Теоретична частина. Дослідження у галузі інноваційних систем проводять багато вітчизняних та зарубіжних учених, зокрема Ю. Бажал, А. Гальчинський, В. Геєць, Л. Гурієва, В. Іванов, Н. Іванова, І. Кузнецова, О. Кузьменко, А. Кусраєв, Б. Лундвала, М. Пашута, В. Семиноженко, Л. Федулова, М. Шарко та ін. У їх працях запропоновано концептуальні підходи до побудови національних інноваційних систем. Проте сучасна динаміка інноваційних процесів в Україні та у світі загалом, враховуючи глобалізаційні процеси, вимагає комплексного дослідження проблем побудови міжнародних інноваційних систем, зокрема міжнародних валеологічних інноваційних систем, та сучасних підходів і механізмів до управління ними.

Методологія. На сучасному етапі розвитку міжнародної інноваційної діяльності практично в усіх виробничих компаніях розвинених країн інтенсифікується міжнародна міжфірмова співпраця, зокрема співпраця з окремих видів науково-дослідної, проектно-конструкторської, дослідно-експериментальної та виробничої діяльності; створення спільних інноваційних підприємств чи об'єднань (консорціумів); розподіл обов'язків між компаніями - засновниками об'єднання; створення науковотехнічних альянсів і організацій різного роду міжнародних інноваційних систем. 
У країнах Карпатського єврорегіону роздержавлення та приватизація спричинили розрив науково-дослідних, виробничо-технологічних та економічних зв'язків, зумовили різноманітність форм власності, що у сукупності, за умов становлення ринкових відносин, потребує вивчення світового досвіду і розроблення сучасних підходів до створення територіальних виробничих об'єднань. Карпатський єврорегіон - єврорегіон в Центральній Європі вздовж Карпатських гір, що об'єднує 19 прикордонних адміністративно-територіальних одиниць; України: Львівську, Івано-Франківську, Закарпатську та Чернівецьку області; Польщі: Підкарпатське воєводство; Словаччини: Кошицький та Пряшівський краї; Угорщини: медьєБоршод-Абауй-Земплен, Гайду-Бігар, Гевеш, Яс-НадькунСольнок та Саболч-Сатмар-Берег; Румунії: повіти Біхор, Селаж, Сату-Маре, Марамуреш, Харгіта, Сучава і Ботошань. Площа єврорегіону становить близько

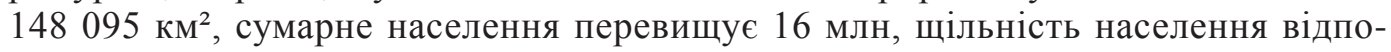

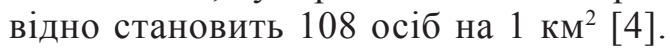

На наш погляд, ВIC - це сукупність взаємозв'язаних організацій (підприємств), зайнятих виробництвом і комерціалізацією валеологічних інноваційних продуктів та продукції у межах кордонів рекреаційних зон, які можуть охоплювати території декількох чи однієї країни. У деяких країнах, у тому числі і в Україні, є декілька рекреаційних зон, а деякі з них знаходяться на кордоні та охоплюють території різних держав, зокрема Поліська, Придунайська, Придністровська, Приазовська, Причорноморська тощо. Інфраструктурними компонентами ВIC можуть бути рекропарки, рекрополіси та курортополіси, рекреаційні бізнес-інкубатори та валеологічні інноваційні центри, а також інститути правового, фінансового i соціального характеру, що забезпечують й обслуговують валеологічні інноваційні процеси. Актуальні і структури, що створюють валеологічну інноваційну політику, враховуючи національні оздоровчі традиції, політичні та культурні особливості різних країн. Тобто МКВІС - інтегрована міждержавна мережа валеологічних інноваційних структур, в основу побудови якої пропонують покласти модель валеологічного інноваційного процесу, його складові можуть знаходитись на різних рівнях організації МКВІС.

Інноваційні валеологічні товари та послуги як кінцевий результат валеологічного інноваційного процесу повинні бути зорієнтовані на підвищення ресурсу здоров'я людини. Але оскільки здоров'я людини можна розглядати як функцію взаємозв'язаних процесів у системі «людина - середовище», то актуальним є дослідження критеріїв, за якими можна було б проводити корекцію здоров'я, формувати та реалізовувати відповідні керуючі впливи до розвитку патологічного процесу і таким чином організовувати інноваційні оздоровчі технології в умовах МКВІС. Найбільш відомі нині такі чотири фундаментальні процеси, що визначають здоров'я людини [1]: відтворення здоров'я - охорона і реалізація генофонду, народження здорового потомства; формування здоров'я - процес, що реалізується під час розвитку та становлення особистості і відповідно регулюється багатьма чинниками, основними 3 яких є спосіб життя та стан навколишнього середовища; споживання здоров'я - повсякденне використання ресурсу здоров'я людини під час її діяльності; відновлення здоров'я - рекреація, лікування i медично-соціальна реабілітація.

Використаний у процесі трудової діяльності потенціал здоров'я відновлюється у період рекреації. У рекреації об'єднуються їі окремі прояви: діагностика здоров'я; організація оздоровчих заходів, зорієнтованих на використання винятково природно-кліматичних засобів оздоровлення; фізичне виховання; туризм; 3 одного боку культурно-масові заходи тощо, з іншого - потреби, інтереси, соціальні установки, зумовлені суспільним значенням рекреації та цінністю здоров'я людини у сучасних соціально-економічних перетвореннях [2]. 
Здоров'я людської популяції оцінюється медично-статистичними показниками (народжуваність, фізичний розвиток, середня тривалість життя, захворюваність, смертність тощо). Що стосується здоров'я людини, то подібними критеріями дотепер є лише ознаки патологічного процесу: якщо вони $є$ - лікар робить висновок, що людина хвора, а якщо їх немає - повне благополуччя. Хоча за наявності тільки однієї альтернативи «здоровий-хворий» можуть мати місце мінімум три варіанти станів людини (рис. 1): здоров'я - оптимальна стійкість до дії патогенних агентів, фізична, психічна та соціальна адаптивність до умов життєдіяльності, які змінюються; проміжний (передпатологічний) стан - можливість розвитку патологічного процесу без зміни впливу діючого чинника внаслідок зниження резервів адаптації; хвороба - патологічний стан.

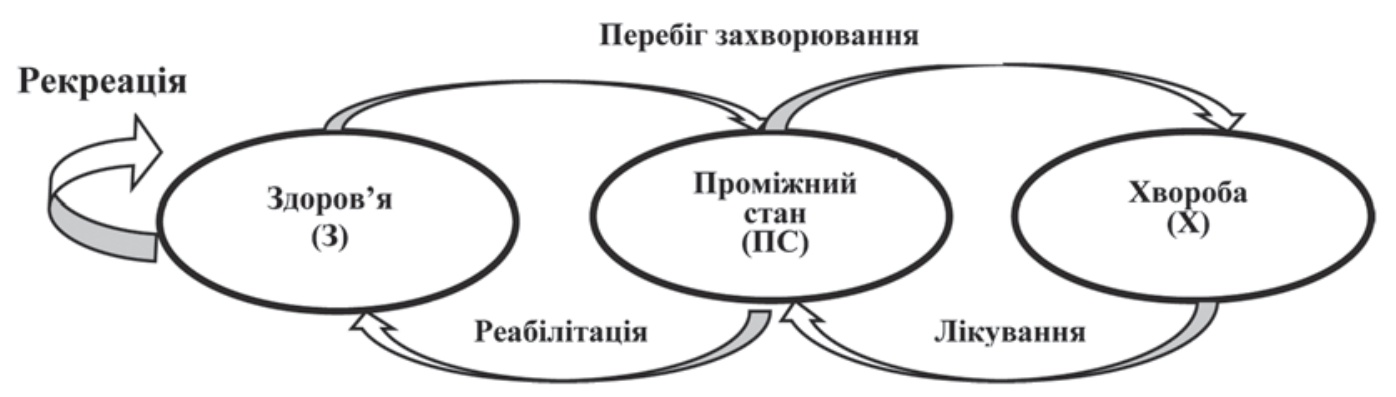

Рис. 1. Графік станів здоров’я людини

Побудову валеологічих інноваційних підприємств (ВІП) як складових МКВІС пропонують проводити на основі організаційної моделі, зображеної на рис. 2.

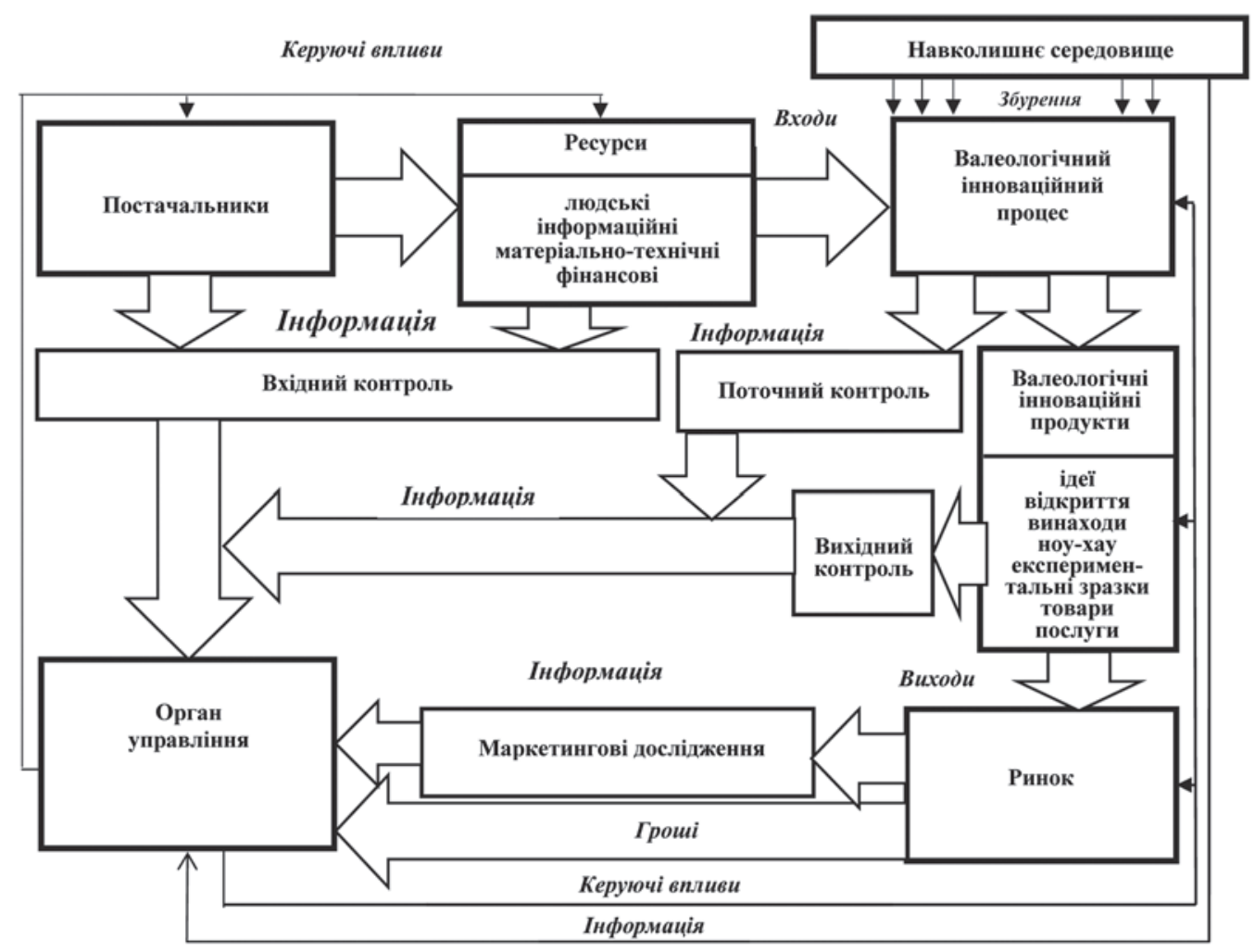

Рис. 2. Модель валеологічного інноваційного підприємства 
Оскільки ефективність ВІП залежить від організації управління ними, то коротко зупинимось на аналізі систем управління ВІП, використовуючи системний, синергетичний, гомеостатичний та синтелектуальний підходи [5].

Системний підхід до управління ВІП вказує на те, що ВІП слід розглядати як економічні системи з множинами взаємозалежних елементів, до яких належать люди, цілі, структура, завдання та технології, зорієнтовані на досягнення головної мети системи і проміжних цілей в умовах ринку та високоентропійного навколишнього середовища. Універсальність моделі системи управління ВІП і алгоритму іiі функціонування неможлива, жодна модель й алгоритм не можуть бути кращими 3 урахуванням динамічних умов, стратегічних та операційних цілей функціонування ВІП. Залежно від умов адаптації ВІП слід розробляти чи вибирати найбільш придатну ситуаційну модель управління і відповідно до неї алгоритм функціонування системи управління ВІП. У загальному модель системи описують як вхід $\{X\}$, процес $\{P\}$, вихід $\{Y\}$, або $S:\{X, P, Y\}$, де елементи множини $X €$ підмножиною (вибірка) з множини ознак (властивостей) об'єкта управління, який збурює навколишнє середовище, іншою системою чи підсистемою. Підмножина властивостей об'єкта, якою володіє дослідник у тому чи іншому аспекті, на які діють параметри з множини входів і які, в свою чергу, впливають на показники (параметри, ознаки, властивості) навколишнього середовища, в системах розглядають як виходи $Y$. Звичайно, елементи множин $\{X\}$ та $\{Y\}$, змінюючи свої значення в часі, на конкретний момент можуть знаходитись у певному стані.

У ВІП як входи $\{X\}$ можуть виступати трудові та природні ресурси, інформація, енергія, матеріали, технологічне обладнання і капітал; процесом $\{P\}$ можна вважати валеологічний інноваційний процес або його складові: науково-дослідне, дослідно-конструкторське та дослідно-експериментальні дослідження, технологічні процеси виробництва, маркетингу і збуту валеологічних інноваційних продуктів чи продукції; виходами $\{Y\}$ - інноваційні продукти і продукцію, прибутки, ефективність діяльності та розвиток ВІП, задоволення потреб співпрацівників тощо. Тобто ВІП можна вважати відкритими і керованими системами. Процеси керованих систем - множина впорядкованих операцій $O_{i}$, що забезпечують перехід від початкового стану входу $X_{o}$ до кінцевого стану виходу $Y^{*}$ - мети системи. Відношення між станами входу і виходу можна представляти математичними моделями і використовувати їх для оцінювання, аналізу i прогнозування станів ВІП.

Як об'єкт управління у ВІП виступають валеологічні інноваційні процеси, а як суб'єкт управління - орган управління. Органи управління слідкують за станами інноваційних процесів на основі вхідного, поточного і вихідного контролів з метою прийняття оптимальних управлінських рішень та забезпечення самоорганізації ВІП. До органу управління надходить також інформація від підрозділів, які слідкують за збуреннями, що надходять з навколишнього середовища, збурюють валеологічний інноваційний процес і можуть виводити його з рівноваги; за ситуацією на ринку, що вимагає включення до структури ВІП служби маркетингу, яка б здійснювала належні маркетингові дослідження. Таким чином, управлінські рішення у ВІП можна приймати та реалізовувати на основі методів управління за збуренням і відхиленням.

Результати та їх обговорення. Оскільки ефективний розвиток ВІП без мети неможливий, то їх доцільно віднести до систем з необмежено цільовим розвитком [5]. Для них не повинно існувати кінцевого стаціонарного інтервалу, оскільки i об'єкту управління (валеологічному інноваційному процесу), і органам управління, що входять до структури ВІП, властивий необмежений характер розвитку. Розвиток ВІП залежить від їх інтеграції в горизонтальні та вертикальні інноваційні 
цикли, взаємодії між рівнями МКВІС. Тому МКВІС пропонують моделювати мережною моделлю, зображеною на рис. 3 у вигляді кластерної, територіальноієрархічної моделі як однієї з різновидностей мережних моделей, складовими якої можуть бути Карпатські валеологічні інноваційні системи (КВІС) країн Карпатського єврорегіону.

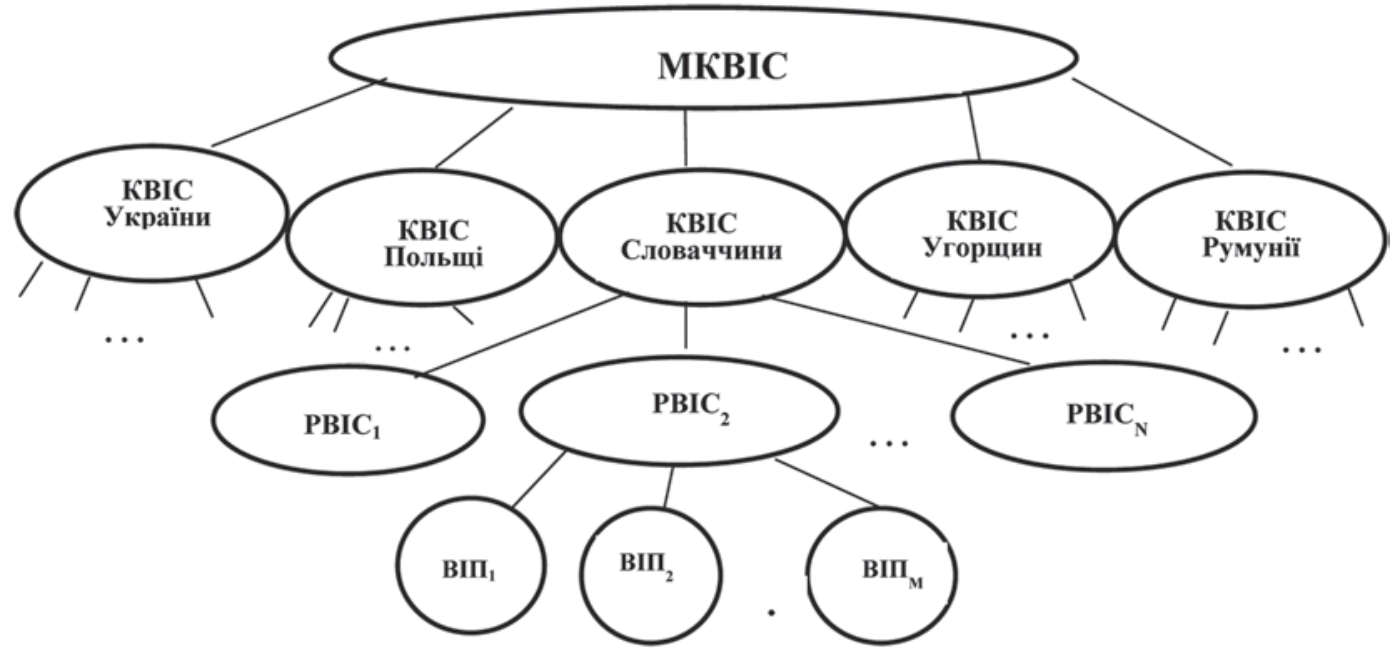

Рис. 3. Модель Міжнародної карпатської валеологічної інноваційної системи

Синергетичний підхід до ефективного управління ВІП доповнює системний підхід та зорієнтований не на зовнішні властивості, цілі і сподівання органу управління ВІП, а на внутрішні властивості ВІП, їхні власні закони еволюції та закони самоорганізації з адаптації до умов навколишнього середовища. При цьому увагу зосереджують на узгодженості управлінського впливу з власними тенденціями динамічного розвитку ВІП, оскільки незначний резонансний вплив у точках біфуркації може зумовити значні зміни у траєкторіях розвитку ВІП. Гомеостатичний підхід до організації управління ВІП дозволяє на основі суперечностей розробити стратегію управління стійким розвитком ВІП і може стати основою для побудови системи управління ВІП відповідно до розроблюваних цільових функцій, які забезпечують ВІП адаптацію до ринкових умов господарювання i, отже, виживання та стійкий розвиток. Синтелектуальні підходи до управління інноваційним розвитком ВІП доцільно розділяти на соціальні та особистісні. Соціальні синтелектуальні підходи - інтелектуалізація людської діяльності і формування у соціумі високоінтелектуального середовища шляхом створення різного роду відкритих та керованих інноваційних систем. Особистісні синтелектуальні підходи до побудови моделей управління ВІП доцільно використовувати при вирішенні психосоматичних проблем розвитку людини.

Побудова МКВІС за запропонованими підходами дозволяє іiї оптимізувати, включати до її складу всі необхідні компоненти, зокрема такі $[2,3,7-11]$ : ті, що створюють спільну валеологічну інноваційну політику та здійснюють міжнародне і державне регулювання валеологічною інноваційною діяльністю; спрямовані на забезпечення суб'єктів валеологічної інноваційної діяльності матеріальними і нематеріальними ресурсами; беруть безпосередню участь у процесі створення, комерціалізації та практичного використання нових валеологічних знань; в умовах єврорегіону, враховуючи глобалізаційні аспекти, посилюють інтеграційні процеси між системами створення, трансферу і практичного вико- 
ристання нового валеологічного знання, здійснюють аналіз міжнародних потоків валеологічних знань та організовують експортно-імпортні операції з валеологічних технологій, патентів, ноу-хау, експериментальних зразків, ліцензій тощо; технологічні альянси між фірмами - резидентами різних держав; міжнародну торгівлю консалтинговими послугами; прямі іноземні інвестиції; спільні міжнародні валеологічні інноваційно-інвестиційні проекти, публікації, симпозіуми, конференції і семінари.

Висновки. Запропонована методологія побудови Міжнародної карпатської валеологічної інноваційної системи може сприяти створенню у країнах Карпатського єврорегіону різного роду ВІП, формуванню і системному становленню валеологічної інноваційної інфраструктури, ефективність функціонування якої зумовлює залучення до валеологічних інноваційних процесів широкого кола різнопрофільних науково-дослідних, проектно-конструкторських, дослідноекспериментальних, виробничих та інших підприємницьких структур, що можуть знаходитись у різних регіонах країн Карпатського єврорегіону.

\section{Спи сок літ ератури}

1. Апанасенко Г.Л. Эволюция биоэнергетики и здоровье человека. - СПб: МГП «Петрополис», 1992.- $123 \mathrm{c}$.

2. Гришова I. Ю., Одрехівський М. В., Сафонов $B$. В. Соціально-економічні передумови та методологічні аспекти побудови національної рекреаційної інноваційної системи // Укр. журн. прикладної економіки / Ukrainian Journal of Applied Economics. - 2016. - T. 1, № 1. - C. 59-67.

3. Иванова Н. Национальные инновационные системы // Вопр. экономики - 2001. № 7. - C. 59-70.

4. Карпатськици єврорегіон // https:// uk.wikipedia.org/wiki

5. Одрехівський М. В. Методологія моделювання валеологічних інноваційних структур // Економічна кібернетика. Міжнар. наук. журн. - 2004. - № 1-2. C. 55-62.

6. Cвim у цифрах 2013 року // The Economist : Пер. А. Корбут. - ECEM Media України, 2013. -256 c. - C. $82-83$.

7. Федулова Л., Пашута М. Розвиток національної інноваційної системи України // Економіка України. - 2005. - № 4. C. 35-47.

8. Шарко М. Модель формування національної інноваційної системи України // Економіка України. - 2005. - № 8. - С. 25-30.
1. Apanasenko G. L. Evolyuciya bioenergetiki i zdorov'e cheloveka. - SPb: MGP «Petropolis», 1992. - $123 \mathrm{p}$.

2. Hryshova I. Yu., Odrekhivskyi M. V., Safonov $V$. V. Sotsialno-ekonomichni peredumovy ta metodolohichni aspekty pobudovy natsionalnoi rekreatsiinoi innovatsiinoi systemy // Ukr. zhurn. prykladnoi ekonomiky / Ukrainian Journal of Applied Economics. 2016. - T. 1, № 1. - P. 59-67.

3. Ivanova $N$. Nacional'nye innovacionnye sistemy // Vopr. ekonomiki - 2001. - № 7. P. 59-70.

4. Karpatskyi yevrorehion // https:// uk.wikipedia.org/wiki

5. Odrekhivskyi M. V. Metodolohiia modeliuvannia valeolohichnykh innovatsiinykh struktur // Ekonomichna kibernetyka. Mizhnar. nauk. zhurn. - 2004. - № 1-2. - P. 5562.

6. Svit u tsyfrakh 2013 roku // The Economist : Per. A. Korbut. - ESEM Media Ukrainy, 2013. - 256 s. - P. 82-83.

7. Fedulova L., Pashuta M. Rozvytok natsionalnoi innovatsiinoi systemy Ukrainy // Ekonomika Ukrainy. - 2005. - № 4. P. 35-47.

8. Sharko M. Model formuvannia natsionalnoi innovatsiinoi systemy Ukrainy // Ekonomika Ukrainy. - 2005. - № 8. - P. 25-30.

9. Asheim B., Isaksen A. Location, agglomeration and innovation: Towards regional innovation system in Norvey? // STEP GROUP Report. - 1996. - Vol. 13. - Oslo. - 64 p.

10. Freeman C. Continental, National and Sub-National Innovation Systems Complementarity and Economic Growth // Research Policy. - 2002. - Vol. 31. - P. 191-211.

11. Lundvall B. National System of Innovation: towards a theory of innovation and interactive learning. - London: Frances Printer, 1992. - 157 p. 


\title{
ПРОБЛЕМЫ ПОСТРОЕНИЯ МЕЖДУНАРОДНОЙ КАРПАТСКОЙ ВАЛЕОЛОГИЧЕСКОЙ ИННОВАЦИОННОЙ СИСТЕМЫ
}

\section{Н. В. Одреховский, О. О. Пиик-Ковальская (Львов)}

Исследованы особенности построения Международной карпатской валеологической инновационной системы на различных уровнях её организации. Обоснована целесообразность создания территориальных производственных объединений. Освещена сущность категории валеологическая инновационная система как совокупность взаимосвязанных организаций (предприятий), занятых производством и коммерциализацией валеологических инновационных продуктов и продукции в пределах границ рекреационных зон, которые могут охватывать территорию как одной, так и нескольких стран. Выделены инфраструктурные компоненты валеологической инновационной системы, к которым отнесены рекропарки, рекрополисы и курортополисы, рекреационные бизнес-инкубаторы и валеологические инновационные центры, а также институты правового, финансового и социального характера, обеспечивающие и обслуживающие валеологические инновационные процессы. Разработана организационная модель валеологического инновационного предприятия. В рамках повышения эффективности работы валеологического инновационного предприятия были проанализированы системы управления им на основе использования системного, синергетического, гомеостатического и синтелектуального подходов. Установлено, что объекту управления (валеологическому инновационному процессу) и органам управления, входящим в структуру валеологического инновационного предприятия, присущий неограниченный характер развития. Обоснована целесообразность моделирования Международной карпатской валеологической инновационной системы сетевой моделью. Данная модель была сформирована в виде кластерной территориально-иерархической модели как одной из разновидностей сетевых моделей, составляющими которой могут быть Карпатские валеологические инновационные системы стран Карпатского еврорегиона.

Ключевые слова: валеологическая инновационная система; валеологический инновационный продукт; валеологическое инновационное предприятие.

\section{PROBLEMS OF CONSTRUCTION OF THE INTERNATIONAL CARPATHIAN VALEOLOGICAL INNOVATION SYSTEM}

\author{
M. V. Odrekhivsky, O. O. Pshyк-Kovalska (Lviv, Ukraine) \\ National University "Lviv Polytechnic"
}

The peculiarities of construction of the International Carpathian Valeological Innovation System at different levels of its organization were investigated. The expediency of creating territorial production associations is substantiated. The essence of the category of valeological innovation system is covered as a set of interconnected organizations (enterprises) engaged in production and commercialization of valeological innovative products within the boundaries of recreational zones, which may cover the territories of several or one country. The infrastructural components of the valeological innovation system are distinguished, which include recreation parks, recropolises and resorts, recreational business incubators and valeological innovation centers, as well as legal, financial and social institutions providing and maintaining valeological innovation processes. The organizational model of the valeological innovation enterprise is developed. In order to increase the efficiency of the Valeological Innovation Enterprise, the systems of its management were analysed based on the use of systematic, synergistic, homeostatic and intellectual approaches.It has been found that the management object (valeological innovation process) and the management bodies that are part of the valeological innovation enterprise structure are characterized by unlimited development.The feasibility of modelling the International Carpathian Valeological Innovation System by network model is substantiated. This model was formed in the form of a cluster, territorial-hierarchical model as one of the varieties of network models, which can be components of the Carpathian valeological innovation systems of the Carpathian Euroregion countries.

Key words: valeological innovation system; valeological innovation product; valeological innovation enterprise. 